\title{
How US Economists Got It So Wrong
}

\section{ROSS MCLEOD ${ }^{1}$}

Paul Krugman recently asked: 'How did economists get it so wrong?' I have great sympathy with his answer: 'Economists...mistook beauty, clad in impressivelooking mathematics, for truth.' But having read the essay I could not help wondering: Is this really a critique of economists in general, or just those in the US? Krugman mentions no fewer than two dozen economists, all but one of whom (with the exception of the long-dead Adam Smith and John Maynard Keynes) are American — or at least based in the US.

It strikes me that in some ways being an academic economist is not unlike being a movie star. The US dominates the English-speaking market for movies. The practical impact of this is that Australian actors such as Cate Blanchett, Toni Collette, Nicole Kidman, Russell Crowe, Anthony LaPaglia, Naomi Watts, Guy Pearce and Heath Ledger need to master American accents and take themselves to Hollywood if they aspire to winning an Oscar. Likewise, the US dominates the English-speaking market for academic economics journals, and nearly all of what are regarded as the world's top universities for teaching economics are in the US. Non-US economists need to present their work in a style consistent with the dominant US approach if they hope to be published in those journals or to obtain positions in those universities. In particular, they experience considerable difficulty if they do not conform to the US obsession with mathematical elegance and econometric (statistical) sophistication. Of course, many US economists face the same dilemma. ${ }^{2}$

I find it disconcerting that in the last two decades there were only two years in which the US did not provide a Nobel-prize winner in economics; and in each of the last 10 years at least one winner has come from the US academic environment. ${ }^{3}$ How does the selection process work? A committee of the central bank of

1 The Australian National University, ross.mcleod@anu.edu.au. The writer is Editor of the Bulletin of Indonesian Economic Studies, published by the Indonesia Project, The Australian National University, Canberra.

2 Hakes, David R. 2009, 'Confession of an Economist: Writing to Impress Rather than Inform', Econ Journal Watch 6(3): 349-51.

3 Although widely known as the Nobel Prize in Economics, the correct designation is 'The Sveriges Riksbank Prize in Economic Sciences in Memory of Alfred Nobel'. 
Sweden chooses the winners, but prior to that a number of candidates need to be nominated, and presumably the committee relies heavily on the supporting documentation supplied to it by those who do the nominating. The nominators are said to be chosen in such a way that as many countries and universities as possible are represented over time, but the identity of such nominators does not seem to be made public. My guess is that US economists are heavily represented in the lists of those eligible to nominate candidates - not least because these include previous recipients of the prize - and that the nominations themselves are also US-dominated. One hears stories of discussions at informal gatherings of top US economists along the lines of 'Whom from among us shall we put forward this year?'. When nearly all of the world's top economics journals and top economics universities are American, it is perhaps not surprising that the distinction between 'us' and 'US' becomes blurred.

One of the unfortunate consequences of US hegemony is that American ways of thinking and doing things tend to overwhelm all else. American best practice comes to be seen as world's best practice, whereas if the global markets for cultural and academic output were more balanced, the world might well be a more interesting place, and better ways of understanding reality might emerge.

Thus Krugman's essay comes down to discussion about contending views over the global financial crisis not within the economics profession, but among economists in the US. The way Krugman frames this debate is as one between what he calls 'freshwater' and 'saltwater' economists (FWEs and SWEs). In this geography, economists outside the US are almost totally ignored. According to Krugman, the FWEs have great faith in the ability of markets to get things right, and little faith in the capacity of fiscal policy to moderate the business cycle, while the SWEs have much less faith in markets and considerably more faith in fiscal policy. He argues that these debates had been largely dormant for many years, but erupted again with the onset of the GFC.

Krugman is so strongly focused on the civil war between American economists that he fails to consider the possibility that they are all missing the point: that government failure, rather than market failure, is to blame for the severe downturn we have been witnessing in the US and many other countries. One therefore gains the impression that the two major schools of thought on macroeconomic policy in the US are so preoccupied with defeating each other on the intellectual battleground that the Keynesian/neo-Keynesian (SWE) versus Chicago School (FWE) debates have simply overlooked certain crucially important matters. 
In fact, governments have made two major policy errors: one of commission and one of omission. In neither case, however, are the underlying economic issues needful of, or readily susceptible to, mathematical analysis, so they have been largely ignored by economists.

In contrast with the voluminous criticism of bankers for the obvious recklessness with which they managed their institutions, comparatively little has been said about the role of the moral hazard that is generated by the practice of governments bailing out banks (and, more recently, other financial institutions) on the grounds that they are 'too big to fail'. This is not to suggest that there is no awareness of the problem, but simply that there has been little attempt to come to grips with it. By comparison with the reams of discussion about whether markets are efficient and whether fiscal policy can stabilise the economy, there has been virtually none on how to deal with the widespread perception among bankers that they can virtually ignore risk without incurring the wrath of their shareholders or depositors, secure in the knowledge that the government will not allow their institutions to fail.

When the US authorities decided to let Lehman Brothers go to the wall, I naïvely imagined that they had finally got the message, for there is probably no better way to get the attention of bank shareholders and depositors than by allowing some of them to lose their shirts. But when Lehman is mentioned these days this policy decision is portrayed, absurdly, as an error that triggered chaos in America's financial sector, the shockwaves from which spread rapidly around the world. The message now seems to be: 'Oops! That was a big mistake. We will never do that again!' But that is equivalent to saying to the financial community: 'Go right ahead. Take all the risks you want. We will back you up with taxpayer money if anything goes wrong.'

How else can we explain the fact that US banks were lending the full purchase price of houses to buyers who were not even employed? That they focused on the relatively recent rapid increase in house prices rather than the fact that they were by now well above their long-term trend? That other institutions were prepared to buy securities backed only by these kinds of assets?

Do those now critical of the Lehman decision seriously believe the same kind of thing will never happen again because older and wiser regulators will do their job better in the future? Do they seriously believe that bank behaviour can be significantly altered by regulating the payment of bonuses to their executives? Policy for the future needs a much firmer foundation than this kind of wishful thinking, and one of the ways in which economists have let the world down is undoubtedly their failure to focus on the moral-hazard problem. 
The second key error of governments has been their failure to devote sufficient attention to one of their most important roles in the economy: providing an efficient legal system. The private sector can run banks but it cannot run a legal system, because it lacks the coercive power of government to settle civil disputes and to punish those who commit crimes.

Of crucial importance in the current context is insolvency law: the legal processes put in train when companies - including banks - become insolvent. In effect, broadly speaking, when a company becomes insolvent, shareholders lose their investment, and creditors share proportionately in the remaining value of the assets - whether the company is liquidated or revived by way of injection of new equity. Unfortunately, however, so little attention has been paid by governments the world over to the design of these processes that they have become extraordinarily drawn out. Creditors often cannot get hold of the residual value of their claims for several years.

It never seems to occur to the authorities, or to economists, that a better designed set of legal arrangements might be able to deal with insolvencies within days rather than years - and that this is precisely what is needed in the case of banks. What makes banks special from the point of view of macroeconomic policy is that they provide the payments mechanism for the entire economy. If depositors cannot get access to their money they cannot spend it, and without spending, economic activity grinds to a halt. This is the reason why central banks act as lenders of last resort and governments create deposit insurance and deposit guarantee schemes - namely, to allow depositors continued access to their funds, even if their bank becomes insolvent.

In a frictionless legal system, bank insolvencies would result in the immediate cancellation of existing shares and the writing-off of a sufficient proportion of deposits and other liabilities so as to return capital to a satisfactory level, thus allowing the bank to continue to operate and depositors to access the remainder of their deposits. One of the key challenges facing the economics profession is to design an insolvency process for banks that comes as close to this frictionless ideal as possible.

The central feature of such a scheme would be a bank regulatory authority with power to freeze the operations of any bank immediately there are plausible concerns about its solvency. Following this, there would be a 'quick and dirty', highly conservative, evaluation of the bank's assets by suitably skilled assessors. Assuming the bank is indeed insolvent on this basis, the existing shares would be cancelled and new equity would be injected by means of writing down the value of all liabilities, proportionately, to an extent sufficient to allow the bank to resume operations. Depositors and other creditors of the bank would thus become its new shareholders. 
Such a process could be implemented within a few days, thus minimising disruption to the payments system. There is now no longer any reason for a run on the bank. Depositors cannot avoid incurring losses because it is already too late. If actual asset values turn out to be higher than the conservative valuations produced initially the newly issued shares will turn out to be more valuable, such that creditors will lose less than first thought. Indeed, if actual asset values turn out to exceed total liabilities, the original shareholders could also recoup some of their investment.

The bottom line is that disruption to the payments system - and therefore to the economy as a whole - is minimised, while losses incurred by the bank are borne, first, by the shareholders, and, second, by creditors (mainly, depositors). There is no cost to the general public, so moral hazard disappears; and banks would be much more prudently managed as a result. This is precisely how the capitalist system is supposed to work when firms become insolvent.

Unfortunately, putting flesh on the bones of proposals such as that outlined here will require assistance from the legal profession and other bankruptcy specialists who may instead be inclined to oppose them, since their large incomes are the direct manifestation of the gross inefficiency of the legal processes relating to insolvency. Moreover, the dominant and highly insular US economics fraternity unwittingly portrayed by Krugman, with its human capital heavily invested in mathematical and econometric virtuosity, seems too strongly inbred with its own ideas to be thinking about extending the debate in the directions indicated, despite its now heightened concerns about the evidently parlous state of macroeconomics. 